Breast Cancer Research and Treatment 7: 5-14, 1986

(C) Martinus Nijhoff Publishers, Boston - Printed in the Netherlands

8th Annual San Antonio Breast Cancer Symposium

\title{
Biological therapy of cancer
}

\author{
Kenneth A. Foon \\ From the Department of Medicine, Division of Hematology and Oncology, University of Michigan, Simpson \\ Memorial Research Institute, 102 Observatory, Ann Arbor, Michigan 48109
}

Key words: anti-idiotype, bone marrow clean up, interferon therapy, monoclonal antibody therapy, toxicity

\section{Summary}

Interferons and monoclonal antibodies are among the most promising biological approaches to cancer treatment which have so far been investigated. Both natural and recombinant interferon-alpha preparations have shown activity in a number of trials in hematologic malignancies, even in previously treated patients; activity in solid tumors, however, has been limited. Unconjugated monoclonal antibodies have been safely administered in several small trials and have had therapeutic value on occasion. In spite of a number of remaining problems and questions, monoclonal antibodies and their conjugates seem likely to find a number of distinct roles in cancer treatment; elimination of micrometastases and purging of bone marrow for grafting may be among these roles.

\section{Introduction}

Progress has been made over the past 5 years toward the development of specific biological approaches to the treatment of cancer. The techniques of genetic engineering and mass cell culture, and improved techniques in protein and nucleic acid sequencing, have made available biologics as highly purified molecules. The most definitive investigations have been carried out with natural and cloned interferon- $\alpha$ preparations, and it is clear that they are capable of inducing responses primarily in patients with certain types of lymphomas and leukemias. Preliminary trials with murine monoclonal antibodies have demonstrated excellent in vivo tumor localization and transient clinical responses; durable responses are rare events. Antibodies conjugated to drugs, toxins, and isotopes have greater antitumor activity in vitro and in animal models, and clinical trials are currently under way.

\section{Interferon}

Interferons are a family of proteins produced by cells in response to virus, double-stranded ribonucleic acid, antigens, and mitogens (1). In addition to antiviral activity (2), the interferons have profound effects on a number of components of the immune system, including $B, T$, and natural killer cells and macrophages $(3,4)$, and have antiproliferative activity $(4,5)$. With respect to the interferons and cancer therapy, it is still unclear whether the interferons work primarily by their antiproliferative activity or through alterations of immune responses. It is clear, however, from both preclinical and clinical studies that interferons have antitumor activity in a number of tumor systems $(6$, 7). 


\section{Leukemias and lymphomas}

The most extensively studied interferons clinically are the natural and recombinant interferon- $\alpha$ preparations. At the National Cancer Institute we recently completed a phase II interferon trial for previously treated patients with non-Hodgkin's lymphoma, chronic lymphocytic leukemia, and cutaneous $T$ cell lymphoma (mycosis fungoides). We chose these diseases because earlier trials with natural interferon- $\alpha$ preparations suggested they would be responsive $(8-10)$. Patients were treated with highly purified recombinant leukocyte $\mathrm{A}$ interferon (Hoffmann-La Roche, Nutley, New Jersey) at $50 \times 10^{6} \mathrm{U} / \mathrm{m}^{2}$ body surface area three times weekly by the intramuscular route; the dose and schedule were based on the maximum tolerated dose from our phase I study (11). Patients were treated for three months, and dose reductions to $50 \%$ and then $10 \%$ of the starting dose were made based on unacceptable toxicity (e.g., fatigue, anorexia, leukopenia, elevated hepatic transaminases).

Eighty-four patients were entered on our phase II lymphoma/leukemia trial. Forty-five of these patients had non-Hodgkin's lymphoma (12), $20 \mathrm{had}$ cutaneous $\mathrm{T}$ cell lymphoma (13), and $19 \mathrm{had}$ chronic lymphocytic leukemia (14). Major toxic reactions observed were fever, chills, fatigue, and anorexia. The average duration of therapy was 2.5 weeks at the $100 \%$ dose and 6.5 weeks at the $50 \%$ dose. Fatigue was the most common reason for dose reduction.
Our results indicated significant antitumor activity for recombinant leukocyte A interferon in patients with low grade and intermediate grade histology non-Hodgkin's lymphoma classified by the Working Formulation (15), and for patients with cutaneous $\mathrm{T}$ cell lymphoma (Table 1). Fiftyfive percent of the patients with low grade and intermediate grade histology non-Hodgkin's lymphoma and nearly $50 \%$ with cutaneous T cell lymphoma responded with either partial or complete responses. All responding patients were maintained on recombinant leukocyte A interferon therapy; the median duration of response was 8 months for non-Hodgkin's lymphoma and 6 months for cutaneous $\mathrm{T}$ cell lymphoma. The five complete responders with low grade and intermediate grade histology non-Hodgkin's lymphoma were shown to be tumor free in sites of previous disease by noninvasive studies and biopsies where indicated. Responses included resolution of bone marrow disease as well as bulky disease in the mediastinum and retroperitoneum $(12,16)$. The responses in patients with cutaneous $\mathrm{T}$ cell lymphoma included reductions of the size of skin plaques and tumors, lymph nodes, and circulating Sézary cells. It was particularly interesting that all of the responding patients had very advanced disease and had failed multiple courses of combination chemotherapy. Recombinant leukocyte $\mathrm{A}$ interferon was not effective in this dose schedule for patients with advanced chronic lymphocytic leukemia, with only 2 partial responses and 11 of 18 evaluable patients progressing while on interferon therapy (14).

Table 1. Clinical Responses in the National Cancer Institute Phase II Recombinant Leukocyte A Interferon Trials for Lymphoproliferative Disorders

\begin{tabular}{|c|c|c|c|c|c|}
\hline Disease* & $\begin{array}{l}\text { Evaluable } \\
\text { patients }\end{array}$ & $\begin{array}{l}\text { Complete } \\
\text { response }\end{array}$ & $\begin{array}{l}\text { Partial } \\
\text { response }\end{array}$ & $\begin{array}{l}\text { Minimal or no } \\
\text { response }\end{array}$ & Progression \\
\hline Low grade NHL & 24 & 4 & 9 & 7 & 4 \\
\hline Intermediate grade $\mathrm{NHL}$ & 6 & 1 & 1 & 1 & 3 \\
\hline High grade NHL & 7 & 0 & 1 & 1 & 5 \\
\hline CTCL & 20 & 0 & 9 & 8 & 3 \\
\hline CLL & 18 & 0 & 2 & 5 & 11 \\
\hline $\mathrm{HCL}$ & 14 & 1 & 12 & 1 & 0 \\
\hline
\end{tabular}

\footnotetext{
* NHL, non-Hodgkin's lymphoma; CLL, chronic lymphocytic leukemia; CTCL, cutaneous T cell lymphoma; HCL, hairy cell leukemia.
} 
We began a phase II trial of recombinant leukocyte A interferon for advanced hairy cell leukemia patients based on the reported excellent results using natural interferon- $\alpha$ (17). Twenty patients were treated with intramuscular and/or subcutaneous injections of recombinant leukocyte A interferon at $3 \times 10^{6} \mathrm{U}$ daily and 14 have completed at least 12 weeks of treatment and are evaluable for response (18). There was one complete response and 12 partial responses for an overall response rate of $93 \%$. All of the partial responders have had a substantial improvement in their hematologic parameters and at a median follow-up of six months not a single patient has relapsed or become refractory to interferon. While only one patient has thus far demonstrated disappearance of bone marrow disease, it does not appear that the absence of hairy cells in the bone marrow is necessary for an optimal clinical response. The only major toxicity was transient myelosuppression during the first week of therapy. Immunologic studies have demonstrated improvement in natural killer activity and lymphoid subpopulations, both coincident with normalization of the hematologic parameters.

Chronic myelogenous leukemia also appears to be responsive to interferon- $\alpha$, with hematologic remission reported in 5 of 7 patients treated (19). These patients had improved hematologic parameters as well as reduction in the size of enlarged spleens and were maintained on $3 \times 10^{6} \mathrm{U}$ of interferon- $\alpha$ daily or every other day.

Our phase II studies have demonstrated that recombinant leukocyte $A$ interferon has the highest reported response rate for any standard or experimental agent in advanced previously treated cutaneous $\mathrm{T}$ cell lymphoma patients. It also establishes recombinant leukocyte $\mathrm{A}$ interferon as a new non-cross-resistant modality of therapy for low grade and intermediate grade histology nonHodgkin's lymphoma. We have also confirmed earlier reports that interferon- $\alpha$ is the most active single agent for hairy cell leukemia and should be considered for therapy when splenectomy is no longer effective in controlling the disease. Finally, interferon- $\alpha$ has activity in chronic myelogenous leukemia. Phase III trials for previously untreated patients with non-Hodgkin's lymphoma, cutane- ous $\mathrm{T}$ cell lymphoma, hairy cell leukemia, and chronic myelogenous leukemia patients are clear avenues of future investigation.

\section{Solid tumors}

Antitumor activity for the alpha interferons has been quite limited for solid tumors. The greatest solid tumor activity has been described for Kaposi's sarcoma with approximately a $50 \%$ response rate $(20,21)$. Results for breast cancer have been mixed, with some responses reported with rather crude Cantell preparations and recombinant preparations of interferon alpha $(10,22,23)$ and interferon beta (24). However, there is also conflicting data suggesting no responses for breast cancer patients treated with recombinant preparations of interferon alpha (25-27). Renal cell carcinoma is among the most unresponsive tumors to any known cytotoxic agents, and approximately a $15 \%$ partial response rate for interferon alpha has been reported for patients with renal cell carcinoma. These results have been reported for crude interferon preparations (28) and cloned agents $(29,30)$. Melanoma is another tumor that has no standard effective chemotherapy; partial response rates of approximately 20 percent have been reported for interferon alpha $(31,32)$. Responses for other common solid tumors such as bronchogenic carcinoma $(33,34)$ and colon cancer $(35,36)$ have been negative. Preliminary trials with crude alpha interferon preparations from Yugoslavia suggested some activity for head and neck cancers $(37,38)$; however, these results have not been confirmed in the United States.

\section{Monoclonal antibodies}

\section{Treatment trials}

Clinical trials with monoclonal antibodies in humans have been designed to approach preliminary questions with respect to the feasibility and toxicity of monoclonal antibody therapy and the rationale for the use of these reagents (39-56) (Table 2). While most of these trials have involved single 
Table 2. Monoclonal Antibody Clinical Trials

\begin{tabular}{|c|c|c|c|c|c|c|c|}
\hline Disease": & $\begin{array}{l}\text { Antibody/ } \\
\text { Class }\end{array}$ & Specificity & $\begin{array}{l}\text { No. of } \\
\text { patients }\end{array}$ & Toxicity & Effect & Institution & Reference \\
\hline B-lymphoma & $\mathrm{Ab} 89 / \operatorname{IgG}_{2 \mathrm{a}}$ & Lymphomas & 1 & Renal (transient) & $\begin{array}{l}\text { Transient reduction } \\
\text { in circulating cells }\end{array}$ & Dana-Farber & 42 \\
\hline B-lymphoma & $4 \mathrm{D} 6 / \lg G_{2 b}$ & Idiotype & 1 & None & $\begin{array}{l}\text { Complete remission } \\
36+\text { months }\end{array}$ & Stanford & 43 \\
\hline B-lymphoma & $\begin{array}{l}\text { Anti-idiotype/ } \\
\operatorname{Ig}_{1} \text { of } \operatorname{IgG}_{2 \mathrm{a}} \\
\text { or } \operatorname{IgG}_{2 \mathrm{~b}}\end{array}$ & Idiotype & 10 & $\begin{array}{l}\text { Fever chills, nausea } \\
\text { vomiting, headache, } \\
\text { diarrhea, transient } \\
\text { dyspnea }\end{array}$ & $\begin{array}{l}5 \text { of } 10 \text { objective } \\
\text { responses }\end{array}$ & Stanford & 44 \\
\hline B-CLL & $\begin{array}{l}\text { Anti-idiotype/ } \\
\lg _{2 b} \text { and } \\
\operatorname{IgG}_{1}\end{array}$ & Idiotype & 1 & Fever, urticaria & $\begin{array}{l}\text { Transient reduction } \\
\text { in circulating cells }\end{array}$ & $\mathrm{NCI}$ & 51 \\
\hline $\mathrm{B}-\mathrm{CLL}$ & $\mathrm{T} 101 / \operatorname{IgG} G_{2 \mathrm{a}}$ & T65 & 13 & $\begin{array}{l}\text { Dyspnea, } \\
\text { hypotension, fever } \\
\left(101-102^{\circ} \mathrm{F}\right)\end{array}$ & $\begin{array}{l}\text { Transient reduction } \\
\text { in circulating cells }\end{array}$ & $\mathrm{NCI}$ & 39 \\
\hline B-CLL & $\mathrm{T} 101 / \operatorname{IgG}_{2 \mathrm{a}}$ & $\mathrm{T} 65$ & 4 & $\begin{array}{l}\text { Dyspnea, } \\
\text { hypotension, fever, } \\
\text { malaise, urticaria }\end{array}$ & $\begin{array}{l}\text { Transient reduction } \\
\text { in circulating cells }\end{array}$ & $\begin{array}{l}\text { U. Calif. San } \\
\text { Diego }\end{array}$ & 40,41 \\
\hline ATL & $\begin{array}{l}\text { L17F12 (anti- } \\
\text { Leu-1)/IgG }_{2 \mathrm{a}}\end{array}$ & Leu-1 & 1 & $\begin{array}{l}\text { Renal, hepatic } \\
\text { (transient) }\end{array}$ & $\begin{array}{l}\text { Transient reduction } \\
\text { in circulating cells }\end{array}$ & Stanford & 48 \\
\hline CTCL & $\mathrm{L}_{17} \mathrm{~F} 12 / \mathrm{IgG}_{2 \mathrm{a}}$ & Leu-1 & 6 & $\begin{array}{l}\text { Dyspnea, hives } \\
\text { cutaneous pain }\end{array}$ & $\begin{array}{l}\text { Minor remission in } 5 \\
\text { of } 7 \text { patients }\end{array}$ & Stanford & 46,47 \\
\hline CTCL & $\mathrm{T} 101 / \operatorname{IgG}_{2: 1}$ & T65 & 12 & $\begin{array}{l}\text { Dyspnea, fever } \\
\left(101-102^{\circ} \mathrm{F}\right)\end{array}$ & $\begin{array}{l}\text { Minor remission in } \\
4 \text { patients }\end{array}$ & $\mathrm{NCI}$ & 45 \\
\hline CTCL & $\mathrm{T} 101 / \operatorname{IgG}_{2: 1}$ & T65 & 4 & Dyspnea, fever & Minor remission & $\begin{array}{l}\text { U. Calif. } \\
\text { San Diego }\end{array}$ & 41 \\
\hline T-ALL & $\begin{array}{l}\mathrm{L} 17 \mathrm{~F} 12 / \operatorname{IgG}_{2 \mathrm{a}} \\
12 \mathrm{E} 7 / \mathrm{IgG}_{\downarrow} \\
4 \mathrm{H} 9 / \mathrm{IgG}_{2 \mathrm{i}}\end{array}$ & $\begin{array}{l}\text { Leu-1 } \\
T \text { \& B cells } \\
\mathrm{T} \text { cells }\end{array}$ & 8 & $\begin{array}{l}\text { Sporadic } \\
\text { coagulopathy }\end{array}$ & $\begin{array}{l}\text { Transient reduction } \\
\text { in circulating cells }\end{array}$ & Stanford & 50 \\
\hline cALL & $\mathrm{J} 5 / \mathrm{IgG}_{\mathfrak{z a}_{1}}$ & CALLA & 4 & Fever $\left(101-102^{\circ} \mathrm{F}\right)$ & $\begin{array}{l}\text { Transient reduction } \\
\text { in circulating cells }\end{array}$ & Dana-Farber & 52 \\
\hline AML & $\begin{array}{l}\mathrm{PM} / 81 / \operatorname{IgM} \\
\text { AML-2-23/ } \\
\operatorname{IgG}_{2 \sqrt{1}} \\
\text { PMN 29/IgM } \\
\text { PMN 6/IgM }\end{array}$ & $\begin{array}{l}\text { NR } \\
\text { NR } \\
\text { NR } \\
\text { NR }\end{array}$ & 3 & $\begin{array}{l}\text { Fever, back pain } \\
\text { arthralgia, myalgia }\end{array}$ & $\begin{array}{l}\text { Transient reduction } \\
\text { in circulating cells }\end{array}$ & Dartmouth & 49 \\
\hline $\begin{array}{l}\text { Gastro- } \\
\text { intestinal }\end{array}$ & $17-1 \mathrm{~A} / \operatorname{IgG}_{2 \mathrm{a}}$ & NR & 20 & $\begin{array}{l}\text { Urticaria, } \\
\text { bronchospasm, mild } \\
\text { hypotension }\end{array}$ & Limited responses & Wistar & 54,55 \\
\hline Melanoma & $9.2 .27 / \mathrm{IgG}_{2 \mathrm{it}}$ & $250 \mathrm{~K}$ & 20 & $\begin{array}{l}\text { Fever, serum } \\
\text { sickness }\end{array}$ & None & $\mathrm{NCI}$ & 53 \\
\hline Melanoma & ${\mathrm{R} 24 / \lg \mathrm{G}_{3}}$ & $\mathrm{G}_{\mathrm{D}: 3}$ & 12 & $\begin{array}{l}\text { Urticaria, pruritis, } \\
\text { fever, wheezing. } \\
\text { vomiting }\end{array}$ & $\begin{array}{l}\text { Major tumor } \\
\text { regressions in } 3 \\
\text { patients }\end{array}$ & $\begin{array}{l}\text { Memorial } \\
\text { Sloan- } \\
\text { Kettering }\end{array}$ & 56 \\
\hline
\end{tabular}

* cALL, common acute lymphoblastic leukemia; ATL, adult T cell leukemia-lymphoma; CTCL, cutaneous T cell lymphoma; B-CLL, B chronic lymphocytic leukemia; AML, acute myelogenous leukemia; NR, not reported. 
patients or small series of patients, early indications are that monoclonal antibody alone may have some therapeutic effect, albeit rather limited.

Forty patients with B cell derived chronic lymphocytic leukemia and cutaneous T cell lymphoma have been treated with the T101 or the anti-Leu-1 antibodies, which recognize a 65 to 69,000 molecular weight glycoprotein antigen (39-42, 45-48). Patients in these studies have been treated with 1-12 dosages ranging from 7 to $1000 \mathrm{mg}$ (single doses ranging from 1 to $150 \mathrm{mg}$ ). Transient reductions in circulating leukemia cell counts were described in most of these patients; however, they were rarely sustained beyond 24 to 48 hours after the completion of therapy. A number of patients with cutaneous $T$ cell lymphoma demonstrated transient reductions in the size of cutaneous skin lesions and enlarged lymph nodes. In these studies, in vivo antibody localization to tumor cells in the peripheral blood, bone marrow, lymph nodes, and cutaneous lesions was identified.

Four patients with acute lymphoblastic leukemia were treated with escalating doses of the J5 monoclonal antibody, which binds to the common acute lymphoblastic leukemia antigen (CALLA) (52). In this study, patients demonstrated transient reductions in the circulating leukemia cells immediately following therapy with J5 antibody, and they demonstrated in vivo antibody localization to circulating and bone marrow tumor cells. Antimurine antibody responses were not described; however, resistance to therapy was mediated in part by antigenic modulation of CALLA (loss of antigen from the cell surface membrane) in response to treatment with $\mathrm{J} 5$ antibody.

A series of IgM monoclonal antibodies recognizing glycolipid determinants on acute myelogenous leukemia (AML) cells and an $\operatorname{IgG}_{2 \mathrm{~b}}$ antibody recognizing a protein on the surface membrane of AML cells were studied in a therapy trial of 3 patients (49). Transient declines in circulating AML cells were reported with evidence of in vivo binding to circulating leukemia cells. No antigenic modulation was demonstrated with any of these antibodies. Human antimurine antibody responses were demonstrated in one of three patients. Toxicity was limited to mild fever, back pain, arthralgia, and myalgia.
We have recently completed a Phase I trial with escalating doses of the antimelanoma monoclonal antibody 9.2.27 which recognizes a 250 -kd glycoprotein/proteoglycan complex (53). Doses from 1 to $500 \mathrm{mg}$ were administered intravenously to patients with disseminated melanoma. Biopsies of skin nodules were taken prior to treatment to confirm the presence of the antigen recognized by 9.2.27. Subsequent biopsies were taken after intravenous administration of 9.2.27 to evaluate the presence of antibody binding in vivo on the tumor cells. Antibody binding in vivo could be demonstrated at doses above $10 \mathrm{mg}$, by either flow cytometry or immunoperoxidase techniques. Doses between 200 and $500 \mathrm{mg}$ were required to saturate all of the antigenic sites on the tumor cells on each nodule. Excellent selectivity of in vivo localization was seen, with staining of the melanoma cells within the nodules and no staining of the surrounding non-melanoma tissues. Antimouse antibody responses were demonstrated in one third of the patients, but they did not detectably impair the ability of the antibody to localize on tumor cells.

Sears and co-workers $(54,55)$ have treated 20 patients with metastatic gastrointestinal malignancies with the 17-1A $\operatorname{IgG}_{2 \mathrm{a}}$ monoclonal antibody. All but 2 patients received a single injection in a dose range of 15 to $1000 \mathrm{mg}$ per patient. Mouse antibody circulated in the patients' blood for 2 to 50 days and was identified in tumor tissues within 1 week of administration. Three patients remained tumorfree 22,13 , and 10 months after monoclonal antibody therapy.

Houghton and co-workers have reported 3 of 12 partial responses in patients with melanoma treated with an $\operatorname{IgG}_{3}$ antibody designated $R_{24}$, which recognizes $G_{D_{3}}$, a prominent ganglioside on the surface of melanoma cells (56). Interestingly, this antibody is cytotoxic in vitro with human complement and human effector cells, and inflammatory reactions were observed around tumor sites in some of the patients treated with this antibody.

\section{Toxicity}

Toxicities associated with monoclonal antibody 
therapy are generally quite mild. Fevers, chills, and urticaria are quite common but are not treatmentlimiting toxicities. Rare patients have developed shortness of breath associated with the rapid infusion of monoclonal antibodies, but this was not seen when the antibodies were infused at $<5 \mathrm{mg} / \mathrm{h}$ $(39,41,44,45)$. Occasional patients have developed hypotension and tachycardia following the infusion of murine monoclonal antibodies (39-41). A limited number of patients have developed transient reduction in their creatinine clearance and elevation of their liver enzymes $(42,48)$, thought to be secondary to immune complexes between monoclonal antibody and circulating antigen. In conclusion, murine-derived monoclonal antibodies can be safely infused; although side effects can be expected and are usually mild.

\section{Anti-idiotype antibodies}

Anti-idiotype monoclonal antibodies differ from other types of antibodies in that they are tumorspecific in the case of B cell derived tumor cells. Immunoglobulin molecules have a unique region in their variable region termed the 'idiotype', and the idiotype for every immunoglobulin molecule is different. Since B cell diseases are clonal diseases, each tumor cell expresses the same immunoglobulin molecule; therefore, the idiotype is identical on every tumor cell. In this unique situation, the idiotype is, therefore, a 'tumor-specific' antigen. A group of investigators from Stanford developed a monoclonal antibody to the idiotypic determinant from a patient with $\mathrm{B}$ cell lymphoma who had become resistant to cytotoxic drugs and interferon (57). The patient had a complete and durable $(>3$ years) response to anti-idiotype antibody therapy (43). An additional 8 patients with non-Hodgkin's lymphoma treated at Stanford and one with chronic lymphocytic leukemia treated at the $\mathrm{Na}$ tional Cancer Institute have had only partial remissions or no responses at all. While anti-idiotype antibody therapy represents the most specific approach to monoclonal antibody therapy for $\mathrm{B}$ cell derived cancer, there are a number of problems. Generating anti-idiotype antibodies is labor intensive and is not practical on a large scale. Hopefully, this process can be refined as new techniques to develop these antibodies are developed. In addition, anti-idiotype antibodies are patient specific and, therefore, can be used to treat only a single patient. Two additional problems have recently been identified and will limit the therapeutic role for anti-idiotype antibody therapy. First, some tumors are biclonal and would require more than one antibody for successful therapy $(58,59)$. Second, the idiotype may be unstable on some patients' tumor cells, probably because of somatic mutation within the variable region gene $(60,61)$.

\section{Problems in antibody therapy}

There are additional obstacles to successful antibody therapy that are common to all murine-derived monoclonal antibodies. 'Antigenic modulation' is the loss of antigen from the cell surface membrane and occurs within minutes or hours after exposure to antibody. During the time that the cells are modulated, they no longer bind to antibody. The modulated cells will usually reexpress the antigen within 24 to 48 hours after the antibody infusion has been completed (when residual antibody is no longer in the serum). While modulation may be a problem for therapy with unconjugated free antibody, it may have a positive effect on immunoconjugate therapy. The antitumor effect of immunoconjugates may be greater when there is internal modulation of the immunoconjugate-antigen complex, which has been demonstrated to take place in a number of systems $(62,63)$.

Murine-derived monoclonal antibodies can also stimulate the development of human antibodies to the murine immunoglobulin. This has been a limiting factor in some of the therapies with monoclonal antibodies, particularly in patients who are immunologically intact (64). This problem might be overcome by using low-dose cytotoxic agents with the initial antibody infusion to destroy these antibody-producing clones. Human derived monoclonal antibodies would eliminate this problem, although responses to the idiotype or allotype of human immunoglobulin would still be possible. Finally, infusing high doses of antibody $(>400 \mathrm{mg}$ ) 
at the onset of therapy might induce tolerance (55).

Another problem with some antibody-tumor systems is tumor heterogeneity, with only a portion of the tumor cells reacting with a single antibody. This might be overcome by using multiple monoclonal antibodies to treat such a tumor.

Finally, monoclonal antibodies do not appear to be very effective in eliminating the tumor cells by themselves. Preclinical animal models suggest that antibodies conjugated to drugs, toxins, and radioisotopes are more cytotoxic and capable of far greater antitumor effects $(65,66)$. This is a major direction of current research.

\section{Bone marrow clean up}

Another attractive therapeutic application of monoclonal antibodies is to 'clean up' autologous bone marrow prior to bone marrow transplantation. Patients who are in clinical remission will often have morphologically undetectable tumor cells in their bone marrow which theoretically could be detected and destroyed with specific antibodies and complement (or antibodies conjugated to toxins). Most of the obstacles and toxicities with monoclonal antibody infusion would be eliminated using this technology. Such an approach has been reported using $\mathrm{B} 1$ monoclonal antibody to clean up autologous bone marrow from patients with nonHodgkin's lymphoma (67). Eight patients who had relapsed with B cell non-Hodgkin's lymphoma were first induced into a minimum disease state (with $<5 \%$ bone marrow involvement with tumor). Bone marrow was then removed and treated with anti-B1 antibody and complement. Patients were then treated with intensive chemoradiotherapy and were reconstituted with anti-B1 treated autologous bone marrow. All patients achieved a complete clinical response and engrafted by 8 weeks. There was no significant toxicity; $B$ cells were detected by 2 months after transplantation and normal immunoglobulin levels were achieved by 6 months. Six of 8 patients were disease free in unmaintained remission for 3 to 20 months after transplantation. Similar results have been reported for the $J 5$ antibody and patients with acute lymphoblastic leukemia (68). Results of these trials are preliminary but have clearly demonstrated that antibody-treated autologous bone marrow is capable of restoring hematopoiesis. Long-term disease-free survival will be necessary before concluding that these therapies have been successful.

\section{Conclusions}

Interferons have shown activity in a number of hematologic malignancies, even in previously treated patients; Phase III trials with untreated patients appear justified. Responses to interferons in most solid tumors, however, have been limited in preliminary trials.

The use of monoclonal antibody immunoconjugates in the treatment of cancer is in its infancy. While much work needs to be done to clarify many of the issues surrounding the use of monoclonal antibodies, it has been clearly demonstrated in both animal tumor models and humans that both antibodies alone and antibody conjugates can be safely administered with minimal adverse effects and, in selected cases, can have therapeutic value.

Problems such as antigenic modulation, host antibody response, and antigenic heterogeneity are all major obstacles to safe and effective therapy with monoclonal antibodies. These issues are under investigation in animal models and humans.

While anti-idiotype antibodies are highly specific and have demonstrated excellent responses in a small number of patients, problems such as biclonality of some lymphomas, instability of the idiotype, and the difficulty of making 'tailor-made' antibodies for individual patients clearly limit the role of anti-idiotype therapy.

Purging of bone marrow with antibodies and complement (or coupled to toxins) is limited to only a few diseases. However, studies thus far have demonstrated that tumor cells can be removed from the bone marrow by in vitro treatment with antibody and complement, and that this treated bone marrow can successfully engraft; a number of patients have been rendered disease-free for over one year. This may prove to be an important application of monoclonal antibody therapy, and it by- 
passes most of the problems with monoclonal antibody infusion therapy described above.

Perhaps the most important future role for monoclonal antibody therapy will be in patients with minimal disease in the 'adjuvant' setting, where immunoconjugates may localize and destroy micrometastatic deposits of tumor cells. We remain cautiously optimistic in exploring these exciting new approaches to cancer therapy.

\section{References}

1. Stewart WE: The Interferon System. Springer-Verlag, New York, 1979, pp 292-304

2. Isaacs A, Lindenmann J: Virus interference. I. The interferons. Proc R Soc Lond [B] 147: 258-67, 1957

3. Borden EC, Edwards BS, Hawkins MJ, et al: Interferons: biological response modification and pharmacology. In: Mihich E (ed) Cancer: Progress Toward Potential Applications. Plenum, New York, 1982, pp 169-218

4. Borden EC, Fall LA: Interferons: biochemical, cell growth inhibitory, and immunological effects. Prog Hematol 12: 299-399, 1981

5. Gresser I, Brouty-Boyé D, Thomas M-T, et al: Interferon and cell division. I. Inhibition of the multiplication of mouse leukemic L1210 cells in vitro by interferon preparations. Proc Natl Acad Sci USA 66: 1052-8, 1970

6. Gresser I: Antitumor effects of interferon. In: Becker F (ed) Cancer - A Comprehensive Treatise. Plenum, New York, 1977, pp 521-72

7. Kirkwood JM, Ernstoff MS: Interferons in the treatment of human cancer. J Clin Oncol 2: 336-52, 1984

8. Merigan TC, Sikora K, Breeden JH, Levy R, Rosenberg $\mathrm{SA}$ : Preliminary observations on the effect of human leukocyte interferon on non-Hodgkin's lymphoma. N Engl J Med 299: 1449-53, 1978

9. Louie AC, Gallagher JG, Sikora K, Levy R, Rosenberg SA, Merigan TC: Follow-up observations on the effect of human leukocyte interferon on non-Hodgkin's lymphoma. Blood 58: 712-8, 1981

10. Gutterman JU, Blumenschein GR, Alexanian R, et al: Leukocyte interferon-induced tumor regression in human metastatic breast cancer, multiple myeloma, and malignant lymphoma. Ann Int Med 93: 399-406, 1980

11. Sherwin SA. Knost JA, Fein S, et al: A multiple dose phase I trial of recombinant leukocyte $A$ interferon in cancer patients. JAMA 248: 2461-6, 1982

12. Foon KA, Sherwin SA, Abrams PG, et al: Treatment of advanced non-Hodgkin's lymphoma with recombinant leukocyte A interferon. N Engl J Med 311: 1148-52, 1984

13. Bunn PA, Foon KA, Ihde DC, et al: Recombinant leukocyte $A$ interferon: an active agent in advanced cutaneous $T$ cell lymphoma. Ann Intern Med 109: 484-7, 1984
14. Foon KA, Bottino GC, Abrams PG, et al: A phase Il trial of recombinant leukocyte $\mathrm{A}$ interferon for patients with advanced chronic lymphocytic leukemia. Am J Med 78: 216-20, 1985

15. The non-Hodgkin's lymphoma pathologic classification project, National Cancer Institute sponsored study of classification of non-Hodgkin's lymphomas. Summary and description of a working formulation for clinical usage. Cancer 49: 2112-35

16. Stevenson HC, Ochs JJ, Halverson L, Oldham RK, Sherwin SA, Foon KA: Dramatic response to retreatment with recombinant alpha interferon with resolution of pulmonary complications of lymphoma. Am J Med 77: 355-8, 1984

17. Quesada JR, Reuben J, Manning JR, Hersh EM, Gutterman JU: Alpha interferon for induction of remission in hairy-cell leukemia. N Engl J Med 310: 15-8, 1984

18. Foon KA, Maluish AE, Abrams PG, et al: Recombinant leukocyte $A$ interferon therapy for advanced hairy cell leukemia: therapeutic and immunologic results. Am J Med (in press)

19. Talpaz M, McCredie KB, Mavligit GM, Gutterman JU: Leukocyte interferon-induced myeloid cytoreduction in chronic myelogenous leukemia. Blood 72: 689-92, 1983

20. Krown SE, Real FX, Cunningham-Rundles S: Preliminary observations on the effect of recombinant leukocyte $\mathrm{A}$ interferon in homosexual men with Kaposi's sarcoma. N Engl J Med 308: 1071-1076, 1983

21. Groopmen JE, Gottlieb MS, Goodman J, et al: Recombinant alpha-2 interferon therapy for Kaposi's sarcoma associated with the acquired immunodeficiency syndrome. Ann Int Med 100: 671-676, 1984

22. Borden EC, Holland JF, Dao TL, et al: Leukocyte-derived interferon (alpha) in human breast carcinoma. The American Cancer Society Phase II Trial. Ann Intern Med 97: 1-6, 1982

23. Smedley H, Katrak M, Sikora K, et al: Recombinant human interferon in advanced breast cancer. Br J Cancer 47: 566-567, 1983

24. Quesada JR, Gutterman JU, Hersh EM: Clinical and immunological study of beta interferon by intramuscular route in patients with metastatic breast cancer. J Interferon Res 2: 593-599, 1982

25. Sherwin SA, Mayer D, Ochs J, et al: Recombinant leukocyte $A$ interferon in advanced breast cancer. Ann Intern Med 98: 598-602, 1983

26. Muss H, Caponera M, Stuart J, et al: Intravenous interferon $\alpha-2$ (rIFN- $\alpha 2)$ in patients with advanced breast cancer: A phase II study. Proc Am Soc Clin Oncol 2: 99 (abstract), 1983

27. Sarna GP, Figlin RA: Phase II trial of $\alpha$-lymphoblastoid interferon given weekly as treatment of advanced breast cancer. Cancer Treat Rep 69: 547-549, 1985

28. Quesada JR, Swanson DA, Trindade A, et al: Renal cell carcinoma: Antitumor effects of leukocyte interferon. Cancer Res 43: 940-947, 1983

29. Quesada JR, Gutterman JU, Rios A: Investigational 
therapy of renal cell carcinoma with recombinant alpha interferon (abstract). Proc Am Assoc Cancer Res 24: 195, 1983

30. Krown SE, Einzing AL, Abramson JD, et al: Treatment of advanced renal cell cancer with recombinant leukocyte $A$ interferon (abstract). Proc Am Soc Clin Oncol 2: 54, 1983

31. Ernstoff MS, Reiss M, Davis CA, et al: Intravenous (IV) recombinant alpha-2 interferon (IFN alpha-2) in metastatic melanoma (abstract). Proc Am Soc Clin Oncol 2: 57, 1983

32. Creagan ET, Ahman DL, Green SJ, et al: Recombinant leukocyte $\mathrm{A}$ interferon (RO 22-8181 rIFN alpha-A) in disseminated malignant melanoma (DMMM) (abstract). Proc Am Soc Clin Oncol 2: 58, 1983

33. Krown SE, Stoopler MB, Cunningham-Rundles $\mathrm{S}$, et al: Phase II trial of human leukocyte interferon in non-small cell lung cancer (abstract). Proc Am Assoc Cancer Res 21: 179,1980

34. Figlin RA, Sarna GP: Human leukocyte interferon (alpha IFN): Phase II trials in non-small cell lung cancer (NSCLC) and adenocarcinoma of the colon and rectum (abstract). Proc Am Soc Clin Oncol 2: 45, 1983

35. Neefe J, Smith F, Fein S, et al: A phase II trial of genetically engineered clone $\mathrm{A}$ alpha interferon (IFL-rA) in a previously untreated advanced colon cancer (abstract). Proc Am Soc Clin Oncol 2: 52, 1983

36. Silgals RM, Ahlgran J, Neefe J, et al: A phase II study of high dose interferon alpha- 2 in advanced colorectal cancer. Cancer Treat Rep, in press

37. Ikic D, Padovan I, Barodarec I, et al: Application of human leukocyte interferon in patients with tumors of the head and neck. Lancet 1: 1025-1027, 1981

38. Padovan I, Brodarec I, Ikic D, et al: Effect of interferon in therapy of skin and head and neck tumors. J Cancer Res Clin Oncol 100: 295-310, 1981

39. Foon KA, Schroff RW, Bunn PA, et al: Effects of monoclonal antibody therapy in patients with chronic lymphocytic leukemia. Blood 64: 1085-94, 1984

40. Dillman RO, Shawler DL, Sobel RE, et al: Murine monoclonal antibody therapy in two patients with chronic lymphocytic leukemia. Blood 59: 1036-45, 1982

41. Dillman RO, Shawler DL, Dillman JB, Roystan I: Therapy of chronic lymphocytic leukemia and cutaneous $\mathrm{T}$ cell lymphoma with T101 monoclonal antibody. J Clin Oncol 2: 88191, 1984

42. Nadler LM, Stashenko P, Hardy R, et al: Serotherapy of a patient with a monoclonal antibody directed against a human lymphoma-associated antigen. Cancer Res 40: 3147-54, 1980

43. Miller RA, Maloney DG, Warnke R, Levy R: Treatment of $B$ cell lymphoma with monoclonal anti-idiotype antibody. N Engl J Med 306: 517-22, 1982

44. Meeker TC, Lowder J, Maloney DG, et al: A clinical trial of anti-idiotype therapy for B cell malignancy. Blood 65 : 1349-1363, 1985

45. Foon KA, Schroff RW, Sherwin SA, Oldham RK, Bunn PA, Hsu S-M: Monoclonal antibody therapy of chronic lymphocytic leukemia and T cell lymphoma: Preliminary observations. In: Boss BD, Langman RE, Towbridge IS, Dulbecco R (eds) Monoclonal Antibodies and Cancer. Academic Press, New York, 1983, pp 39-52

46. Miller RA, Levy R: Response of cutaneous T cell lymphoma to therapy of hybridoma monoclonal antibody. Lancet 2: 225-230, 1981

47. Miller RA, Oseroff AR, Stratte PT, Levy R: Monoclonal antibody therapeutic trials in seven patients with $T$ cell lymphoma. Blood 62: 988-95, 1983

48. Miller RA, Maloney DG, McKillop J, Levy R: In vivo effects of murine hybridoma monoclonal antibody in patient with T cell leukemia. Blood 58: 78-86, 1981

49. Ball ED, Bernier GM, Cornwell GG, McIntyre OR, O'Donnell JR, Fanger MW: Monoclonal antibodies to myeloid differentiation antigens: In vivo studies of three patients with acute myelogenous leukemia. Blood 62: 12031210,1983

50. Levy R, Miller RA: Tumor therapy with monoclonal antibodies. Fed Proc 42: 2650-2656, 1983

51. Giardina SL, Schroff RW, Kipps TJ, et al: The generation of monoclonal anti-idiotype antibodies to human B cellderived leukemias and lymphomas. J Immunol 135: 653658,1985

52. Ritz J, Pesando JM, Sallan, et al: Serotherapy of acute lymphoblastic leukemia with monoclonal antibody. Blood 58: 141-152, 1981

53. Oldham RK, Foon KA, Morgan AC, et al: Monoclonal antibody therapy of malignant melanoma: In vivo localization in cutaneous metastasis after intravenous administration. J Clin Oncol 2: 1235-1244, 1984

54. Sears HF, Mattis J, Herlyn D, et al: Phase I clinical trial of monoclonal antibody in treatment of gastrointestinal tumors. Lancet 1: 762-765, 1982

55. Sears HG, Herlyn D, Steplewski Z, Koprowski H: Effects of monoclonal antibody immunotherapy on patients with gastrointestinal adenocarcinoma. J Biol Resp Modif 3: 138150, 1984

56. Houghton AN, Mintzer D, Cordon-Cardo C, et al: Mouse monoclonal $\operatorname{IgG}_{3}$ antibody detecting GD3 ganglioside: a phase I trial in patients with malignant melanoma. Proc Natl Acad Sci USA 82: 1242-1246, 1985

57. Hatzubai A, Maloney DG, Levy R: Use of a monoclonal anti-idiotype antibody to study the biology of a human B cell lymphoma. J Immunol 126: 2397-2402, 1981

58. Sklar J, Cleary ML, Thielmans K, Gralow J, Warnke R, Levy R: Biclonal B cell lymphoma. N Engl J Med 311: $20-27,1984$

59. Giardina SL, Schroff RW, Woodhouse CS, et al: Detection of two distinct malignant $\mathrm{B}$ cell clones in a single patient using anti-idiotype monoclonal antibodies and immunoglobulin gene rearrangement. Blood 66: 1017-1021, 1985

60. Raffeld M, Neckers L, Longo DL, Cossman J: Spontaneous alteration of idiotype in a monoclonal B cell lymphoma. Escape from detection by anti-idiotype. N Engl J Med 312: 1653-1657, 1985 
61. Meeker T, Lowder J, Cleary ML, Stewart S, Warnke R, Sklar J, Levy R: Emergence of idiotype variants during treatment of $\mathrm{B}$ cell lymphoma with anti-idiotype antibodies. N Engl J Med 312: 1658-1666, 1985

62. Pesando JM, Ritz J, Lazarus K, Tomaselli KJ, Schlossman SF: Fate of a common acute lymphoblastic leukemia antigen during modulation by monoclonal antibody. J Immunol 126: $540-544,1981$

63. Schroff RW, Farrell MM, Klein RA, Oldham RK, Foon $\mathrm{KA}$ : T65 antigen modulation in a phase I monoclonal antibody trial with chronic lymphocytic leukemia patients. J Immunol 133: 1641-1648, 1984

64. Schroff RW, Foon KA, Wilburn SB, Oldham RK, Morgan $\mathrm{AC}$ : Human antimurine immunoglobulin responses in patients receiving monoclonal antibody therapy. Cancer Res, in press

65. Foon KA, Bernhard MI, Oldham RK: Monoclonal antibody therapy: Assessment by animal tumor models. J Biol
Resp Modif 1: 277-304, 1982

66. Hwang KM, Foon KA, Cheung PH, Pearson JW, Oldham RK: Selective antitumor effect of a potent immunoconjugate composed of the $\mathrm{A}$ chain of abrin and a monoclonal antibody to a hepatoma-associated antigen. Cancer Res 44: 4478-86, 1984

67. Nadler L, Takvorian T, Botnick L, Finberg R, Bast R, Hellman S, Cannellos G, Schlossman S: Anti-B1 monoclonal antibody and complement treatment in autologous bone marrow transplantation for relapsed B cell non-Hodgkin's lymphoma. Lancet 2: 427-443, 1984

68. Ritz J, Bast RC, Clavell LA, Hercend T, Sallen SE, Lipton JM, Feeney M, Nathan DG, Schlossman SF: Autologous bone marrow transplantation in CALLA-positive acute lymphoblastic leukemia after in vitro treatment with $\mathrm{J} 5$ monoclonal antibody and complement. Lancet 2: 60-63, 1982 